\title{
粘性土の非排水せん断挙動に及ぼす圧密時間の影響

\author{
EFFECT OF CONSOLIDATION DURATION ON THE UNDRAINED \\ SHEAR BEHAVIOR OF COHESIVE SOILS
}

\author{
小田美 明* ·三田地利之** · 木 藤 勇 \\ By Yoshiaki ODA, Toshiyuki MITACHI and Hayato KITOH
}

\begin{abstract}
In the consolidated undrained test on cohesive soils, consolidation duration influences on the undrained shear behavior. Consequently, appropriate criterion for judging end of consolidation is required.

In order to study the applicability of the square root time fitting method and the usefulness of $3 t$ method (JSSMFE, 1979) to determine consolidation duration, a series of consolidated undrained triaxial compression test with different consolidation duration on four normally consolidated cohesive soils was performed. Based on the test results, it was shown that the square root time fitting method can be applicable to triaxial isotropic consolidation, but $3 t$ method is better to minimize the influence of consolidation duration on the stress-strain-strength behavior of cohesive soil during undrained shear process.
\end{abstract}

Keywords : cohesive soil, consolidated undrained shear, shear strength

\section{1.はじめに}

粘性土:の圧密非排水圧縮試験において，圧密時間の増 加に伴い, 圧縮強さが増加することが知られている ${ }^{11 \sim 10)}$. したがって, 圧密非排水試験を行う際, 圧密終了判定の ための的確な規準が必要である。しかし, 粘性土の変形, 強度特性:に及ぼす圧密時間の影響についての研究の多く は, 二次圧密領域についてのものであり, 通常業務とし て行われる圧密時間の範囲のものは少ない.

三笠ら ${ }^{21}$ は, 4 種類の粘性土についての改良型一面せ ん断試験機による実験結果から圧密時間とせん断強さの 関係について報告している.これらの結果から通常業務 としてせん断試験を行う際の指針として間隙水圧がゼロ となる圧密時間を選ぶのが妥当だとし, 一応の目安とし て曲線定規法による $t_{50}$ の 30 倍程度が適当だとしてい る.

三軸等方圧密については, 亀井ら ${ }^{10)}$ が, Yoneyama Red Clay を用いた等方および $K_{0}$ 圧密非排水試験をそ れぞれ压密時間を変えて行い, $3 t$ 法 $^{11}$ による一次圧密

* 正会員 北海道大学助手 工学部土木工学科 ( (1060 札幅市北区北 13 条西 8 丁目)

** 正会員 工博 北海道大学教授 工学部土木工学科(同上)

*** 正会員 北海道旅客鉄道株式会社

(宁1)60 札幌市北区北 5 条西 4 丁目)
終了判定の有効性を報告している. しかし, 試験時間の 短縮が必要な場合には, $2 t$ 法でも良いとしている.

また, 三軸圧密に対して一次元の圧密試験 (JIS A 1217）における $\sqrt{t}$ 法を準用することについては, 沪 紙の透水性をきわめて大きいと仮定し, 汇紙の配置が圧 密速度に及ぼす影響を計算した結果から, 三軸試験の規 格の排水条件では $\sqrt{t}$ 目盛りの曲線に直線部分がなく 適用できない(2) とされている，しかし，著者ら ${ }^{13)}$ は，三 軸等方圧密において排水を周面方向のみに限定した場 合, $\sqrt{t}$ 法が適用可能であること, また, 圧密の載荷段 階数を変えても最終段階の圧密を $\sqrt{t}$ 法による一次圧 密量に相当する時間を越えて 2 時間後に打ち切るように 統一すれば，その後のせん断挙動に影響を及ぼさないこ とを報告している.

三軸等方圧密の終了判定法として, 排水速度が 0.03 $\% / \mathrm{h}$ 以下になった場合を圧密終了とする方法 ${ }^{14)}$ も提案 されている. しかし, 実用的な反面, 載荷段階数や沪紙 の被覆面積に影響されることが考えられる.

また，圧密時間の増加に伴う非排水強度の増加に関す る研究においては, 排水量と時間の対数との関係から得 られる逆 S字形の曲線において, 曲線の中間部のほぼ直 線とみなされる部分の延長と二次圧密領域の直線との交 点を一次圧密終了とする Casagrande $の \log t$ 法を準用 
したもの ${ }^{9)}$ あるいは, 二次圧密領域の直線の開始部分 を一次圧密終了としたもの ${ }^{8)}$ もるが，二次圧密領域が 明確に現われるまで, 圧密を継続する必要があり, 通常 業務における判定法としては難がある.

さらに, 圧密時の体積変化ではなく圧密時の間隙水圧

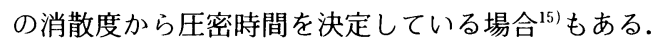

そこで, 本研究は, 4 種類の粘土を用い, 圧密時間を 変え圧密非排水圧縮試験を行って, 三軸等方圧密試験に 対する $\sqrt{t}$ 法の適用性, および $3 t$ 法の有効性について 検討したたもの゙ある.

\section{2. 試料および実験}

\section{（1）試料}

実験に用いた試料は，市販の 2 種類のカオリン粘土と 笠岡粘土および北海道俱知安町近郊から採取した自然粘 土である. 市販の粉末粘土は, 液性限界の 2 倍の含水比 になるよう蒸留水を加えソイルミキサーで十分に摫汼 し, スラリ一状態で養生した。 また, 自然粘土は蒸留水 を加え $420 \mu \mathrm{m}$ のふるいで粗粒分を除いた後, 同様にス ラリー状態で養生した。.このスラリー状態の粘土を大型 予圧密七ルに真空状態で引き込み十分に脱気した後, 力 オリン粘土は $100 \mathrm{kPa}$, 他の粘土は $80 \mathrm{kPa}$ の鉛直応力 で一定期間, 一次元的に予圧密した. 各試料の物理的性

\section{質を Table 1 に示す.}

\section{（2）実験装置}

実験には, 通常の軸対称三軸圧縮試験装置を用いた。 軸力の測定は三軸セル内にセットしたロードセルにより 行った。 また, 間隙水圧の測定は供試体底部中央で行っ た.メンブレーンの透気性, 透水性を考慮して, セル内 を脱気水で満たした，供試体の大きさは，直径 $50 \mathrm{~mm}$,

Table 1 Index properties of samples.

\begin{tabular}{c|c|c|c|c|c|c|c}
\hline Sample & $\begin{array}{c}W_{L} \\
(\%)\end{array}$ & $\begin{array}{c}W_{P} \\
(\%)\end{array}$ & $I_{p}$ & $G_{S}$ & $\begin{array}{c}\text { Sand } \\
(\%)\end{array}$ & $\begin{array}{c}\text { Silt } \\
(\%)\end{array}$ & $\begin{array}{c}\text { Clay } \\
(\%)\end{array}$ \\
\hline Kaolin-1 & 76 & 32 & 44 & 2.75 & 0 & 1 & 99 \\
\hline Kaolin-2 & 85 & 40 & 45 & 2.75 & 0 & 8 & 92 \\
\hline Kasaoka & 62 & 37 & 25 & 2.77 & 18 & 37 & 45 \\
\hline Kucchan & 81 & 40 & 41 & 2.68 & 0 & 23 & 77 \\
\hline
\end{tabular}

Table 2 Test condition.

\begin{tabular}{|c|c|c|c|c|c|}
\hline Sample & $\frac{\Delta P}{P}$ & LS & $\begin{array}{c}\mathrm{P}_{\mathrm{c}} \\
(\mathrm{kPa})\end{array}$ & $\begin{array}{l}F P C \\
(\%)\end{array}$ & $\begin{array}{c}\dot{\vdots} \\
\left(\begin{array}{c}\% \\
\%\end{array}\right)\end{array}$ \\
\hline Kaolin-1 & 5 & 1 & 300 & 70 & \multirow{2}{*}{0.1} \\
\hline Kaolin-2 & \multirow{3}{*}{1} & 4 & 400 & 50 & \\
\hline Kasaoka & & \multirow{2}{*}{3} & \multirow{2}{*}{200} & \multirow{2}{*}{100} & \multirow{2}{*}{0.05} \\
\hline Kucchan & & & & & \\
\hline \multicolumn{6}{|c|}{$\Delta \mathrm{P} / \mathrm{P}$ : Load Increment Ratio } \\
\hline LS & \multicolumn{5}{|c|}{ : Loading Steps } \\
\hline $\begin{array}{l}\mathrm{P}_{\mathrm{C}} \\
\mathrm{FPC}\end{array}$ & \multicolumn{5}{|c|}{ : Isotropic Consolidation Pressure } \\
\hline
\end{tabular}

高さ $120 \mathrm{~mm}$ である. 実験は, すべて, $20 \pm 0.5^{\circ} \mathrm{C}$ の恒 温室内で実施した。

\section{（3）実験条件}

供試体を所定の圧密圧力まで段階的に等方圧密した 後, 非排水条件でひずみ速度一定でせん断した。，圧密時 から $200 \mathrm{kPa}$ のバックプレッシャーを載荷した。圧密 時の排水は, 供試体側面に巻かれた沪紙に向かう半径方 向排水のみに限定し, 上下方向では行っていない。

Table 2 に実験条件を示す。

\section{3. 実験結果および考察}

\section{（1）压密特性}

Fig. 1 は，カオリン-1 粘土についての集水方向を変え た場合の圧密挙動である．この図からわかるように，周 面の沪紙からの排水を間隙水圧測定経路に近い下部 (pedestal) で集水した場合，上部（cap）で集水した 場合よりかなり速く過剩間腺水圧が消散する.しかし， 体積変化は集水方向にかかわらず同じ挙動を示す. 圧密 非排水試験において圧密終了の判定を体積変化からでは

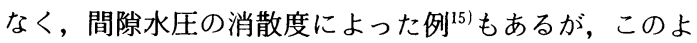
うに集水位置によって測定される間隙水圧の挙動がかな り異なる。したがって, 間隙水圧の消散により圧密終了 の判定をするのは適切ではなく, 体積変化から判定する のが適切だと考えられる. また, 一次元圧密においては, 応力による圧密度が沈下量による圧密度より常に遅れる

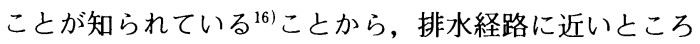
で圧密中の間隙水圧を測定した場合は，その值の信頼性 はかなり低いと考えるべきであろう。

各粘土の圧密挙動を時間の平方根および対数で整理し
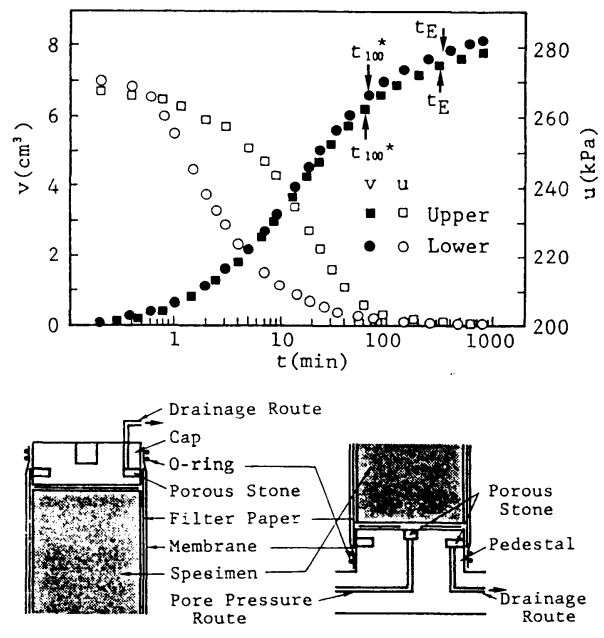

Upper

Lower

Fig. 1 Consolidation characteristics with different position of drainage outlet. 
たものをFig.2(a)，(b) にそれぞれ示す. Fig.2(a) か らわかるように，すべての粘土において，圧密初期に直 線部分がみられ，三軸等方圧密においても $\sqrt{t}$ 法の適 用が可能であるといえる.

これらの図から各粘土について求めた $\sqrt{t}$ 法の準用 による一次圧密量 $v_{100}^{*}$ に対応する時間 $t_{100}^{*}$ と $3 t$ 法によ る圧密終了時間 $t_{E}$ およびその比 $t_{E} / t_{100}^{*}$ を Table 3 に示 す. 別に行った実験から得られたカオリン -2 粘土の沪 紙の被覆面積率 $100 \%$ の場合の值および早来粘土の值 も示してある.この表からわかるように実測された $t_{100}^{*}, t_{E}$ 沈，それぞれかなりのばらつきがある．圧密 時間の短いものについては, $3 t$ 法により $t_{E}$ を求めるこ とができないため, 以下の圧密時間の整理にはこの平均 值を用いる。 また， $t_{E} / t_{100}^{*}$ は，別に行った試験結果か ら粘土に固有なものではなく, 圧密応力の載荷段階数や 沪紙の被覆面積率等により変化することがわかってい る. なお, Table 3 には, 二次圧密係数 $C_{\alpha}$ も示している. カオリン -1 粘土以外の粘土における圧密試験（JIS A 1217）から得られた圧密特性を Table 4 に示している. 圧密試験の荷重段階は, 三軸等方圧密試験と間隙比が近
いものを選定した．これらの表からわかるように，三軸 等方圧密における終了時間を一次元の圧密試験から得ら れる圧密特性で定量的に予測することは難しいが，ある 程度の目安とはなるであろう。

2 種類の圧密終了判定法について検討するため, Fig. 3(a), (b) に圧密時間 $t$ を $\sqrt{t}$ 法および $3 t$ 法によ る圧密時間 $t_{100}^{*}, t_{E}$ で, 排水量 $v$ を同じく $v_{100}^{*}, v_{E}$ で正 規化したものを示す.これらの図からわかるように $\sqrt{t}$ 法による判定では, 圧密開始から $t_{100}^{*}$ までの圧密挙動 は粘土によらず 1 つ曲線で表わすことができる. しか し, 一次圧密後の圧密挙動は粘土の種類によりかなり異 なり，一次圧密量の $20 \%$ 程度圧密が進行する。また， $3 t$ 法による圧密終了では, 圧密開始から $t_{E}$ までは, $\sqrt{t}$ 法之比べて粘土によりやや異なるが， $t_{E}$ 前後の排水 量の増加率は $\sqrt{t}$ 法によるものと比べかなり小さい.

本実験の圧密時間の範囲における各粘土の圧密時間の 最も長い実験から得られた間隙比と $t_{E}$ で正規化した圧 密時間の対数との関係を Fig. 4 に示している. $t_{E}$ 以後 の間隙比は, 時間の対数に比例して減少する傾向となり, 各粘土の二次圧密領域の始まりが $t_{E}$ に対応する傾向が

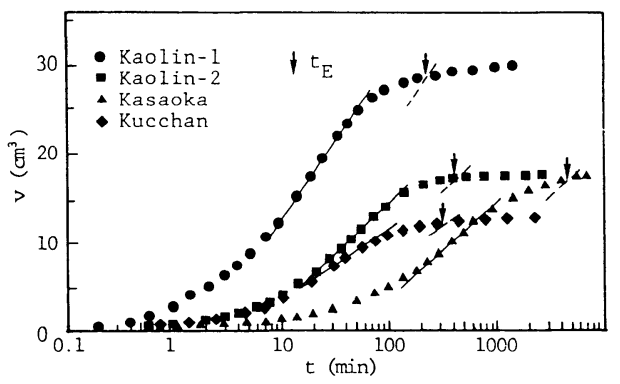

(b) $3 t$ method

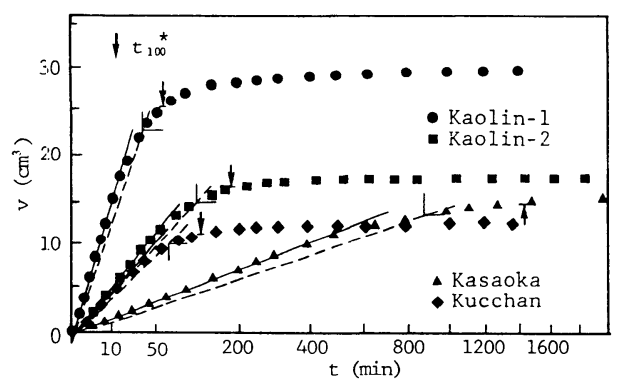

(a) $\sqrt{t}$ method

Fig. 2 Determination of end of consolidation by two methods.

Table 3 Triaxial consolidation characteristics.

\begin{tabular}{|c|c|c|c|c|c|c|c|c|c|}
\hline \multirow{2}{*}{ Sample } & \multirow{2}{*}{$\begin{array}{l}\text { FPC } \\
(\%)\end{array}$} & \multirow{2}{*}{$\begin{array}{r}\mathrm{P}_{\mathrm{c}} \\
(\mathrm{kPa}) \\
\end{array}$} & \multirow{2}{*}{ e } & \multicolumn{2}{|c|}{$\mathrm{t}_{100}{ }^{*}(\mathrm{~min})$} & \multicolumn{2}{|c|}{$t_{E}$ (min) } & \multirow{2}{*}{$\frac{t_{E}}{t_{100}}$} & \multirow{2}{*}{$\begin{array}{c}\mathrm{C}_{\alpha} \\
\times 10^{-2}\end{array}$} \\
\hline & & & & Range & Avg. & Range & Avg. & & \\
\hline Kaolin-1 & 70 & $50+300$ & $1.73+1.38$ & $45 \sim 80$ & 60 & $180 \sim 270$ & 220 & 3.67 & 1.8 \\
\hline \multirow{2}{*}{ Kaolin-2 } & 50 & \multirow{2}{*}{$200 \rightarrow 400$} & $1.56+1.34$ & $140 \sim 200$ & 180 & $380 \sim 450$ & 420 & 2.67 & .44 \\
\hline & \multirow{4}{*}{100} & & $1.58+1.30$ & $65 \sim 110$ & 80 & $180 \sim 300$ & 220 & 2.75 & .44 \\
\hline Kasaoka & & \multirow{2}{*}{$100+200$} & $1.12 \rightarrow 0.95$ & $940 \sim 1720$ & 1440 & $3500 \sim 3900$ & 3700 & 2.57 & 3.3 \\
\hline Kucchan & & & $1.46+1.31$ & $100 \sim 140$ & 120 & $300 \sim 360$ & 320 & 2.67 & 1.1 \\
\hline Hayakita & & $50+300$ & $1.55+1.24$ & $250 \sim 500$ & 350 & $900 \sim 1500$ & 1440 & 4.11 & .90 \\
\hline
\end{tabular}

Table 4 One dimensional consolidation characteristics.

\begin{tabular}{|c|c|c|c|c|c|c|c|c|}
\hline Sample & $\begin{array}{c}\mathrm{P} \\
\left(\mathrm{kgf} / \mathrm{cm}^{2}\right)\end{array}$ & $\mathrm{e}$ & $\begin{array}{c}\mathrm{t}_{10{ }^{\star}} \\
(\mathrm{min})\end{array}$ & $\mathrm{C}_{\mathrm{c}}$ & $\begin{array}{c}\mathrm{C}_{\alpha} \\
\times 10^{2} \\
\end{array}$ & $\begin{array}{c}\mathrm{cv} \\
\left(\mathrm{cm}^{2} / \mathrm{d}\right)\end{array}$ & $\underset{\left(\mathrm{cm}^{2} / \mathrm{kgf}\right)}{\mathrm{m}_{\mathrm{v}}}$ & $\begin{array}{c}\mathrm{k} \\
(\mathrm{cm} / \mathrm{s})\end{array}$ \\
\hline Kaolin-2 & $1.6+3.2$ & $1.49+1.24$ & 5.5 & 0.79 & .60 & $1.5 \times 10^{2}$ & $6.6 \times 10^{-2}$ & $5.5 \times 10^{-8}$ \\
\hline Kasaoka & \multirow{3}{*}{$0.8+1.6$} & $1.17 \rightarrow 1.00$ & 246 & 0.57 & 3.0 & $1.1 \times 10$ & $1.0 \times 10^{-1}$ & $4.5 \times 10^{-9}$ \\
\hline Kucchan & & $1.39+1.26$ & 17 & 0.50 & 1.1 & $4.5 \times 10$ & $6.6 \times 10^{-2}$ & $2.6 \times 10^{-8}$ \\
\hline Hayakita & & $1.31+1.22$ & 30 & 0.41 & 1.0 & $3.1 \times 10$ & $5.1 \times 10^{-2}$ & $1.5 \times 10^{-6}$ \\
\hline
\end{tabular}




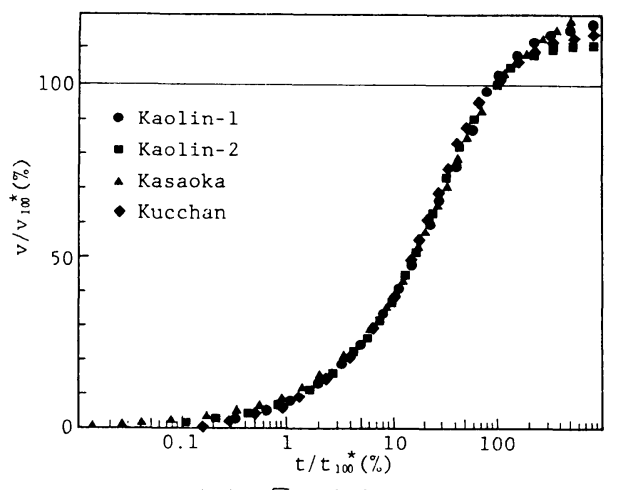

(a) $\sqrt{t}$ method

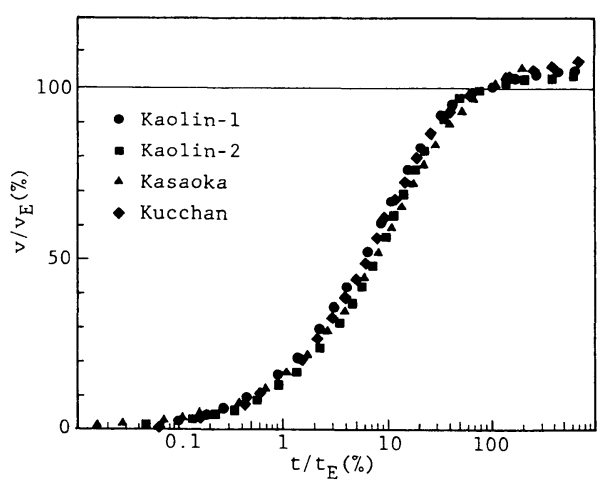

(b) $3 t$ method

Fig. 3 Normalized consolidation curves for four samples.

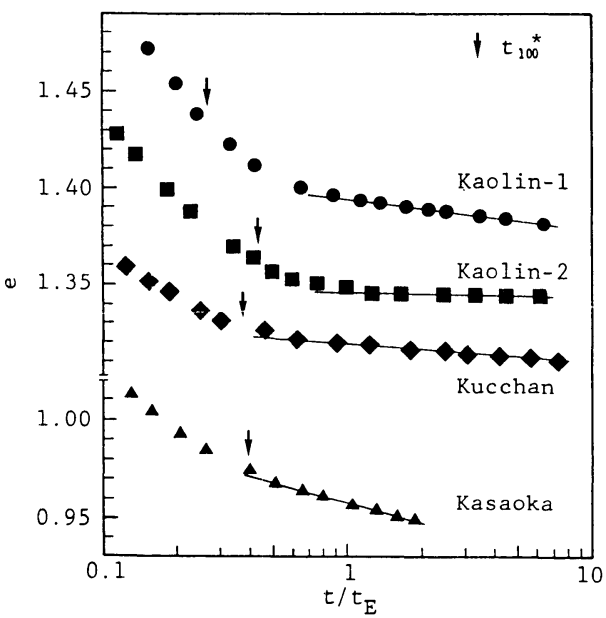

Fig. 4 Void ratio versus elapsed time relationships.

ある。

Fig. 5(a)，(b) は，カオリン -2 粘土を用い排水用の沪 紙の供試体周面積に対する比率 $F(\%)$ を変えて行った

三軸等方圧密試験の結果を Fig. 3 と同様, $\sqrt{t}$ 法および

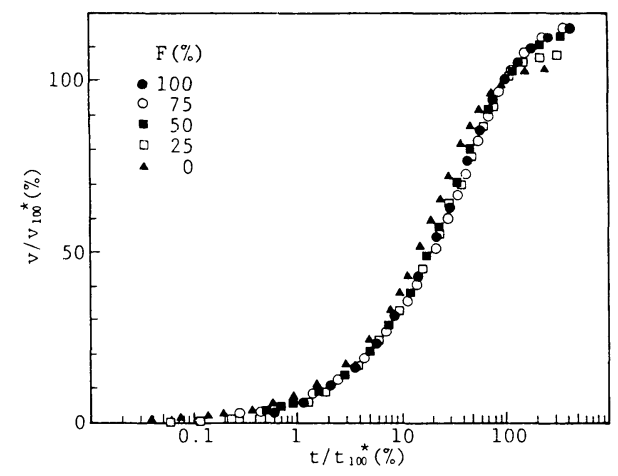

(a) $\sqrt{t}$ method
$3 t$ 法による時間と排水量で正規化したものである.こ れらの図からわかるように，同一粘土においても $\sqrt{t}$ 法による判定では, 一次圧密終了後の圧密挙動が面積率 の影響を大きく受ける傾向となる. しかし，3t法で整 理した場合は, 面積率の影響を受けず 1 本の曲線とみな すことができる. また, 二次圧密係数は, 面積率の影響 を受けず一定であった。

沪紙も応力の増加により圧縮するこよが知られてい $3^{17), 18)}$. 本実験で用いた沪紙と粘土において，汇紙の排 水量の補正式 ${ }^{18)}$ から求めた圧密最終段階の沪紙の排水量 は全排水量の $3 \%$ から $9 \%$ であった．沪紙の透水性は， 供試体よりかなり大きいため, 圧密過程の初期で測定さ れる排水量に沪紙からの排水量の影響が含まれる。した がって, 沪紙の被覆面積が大きい場合, 圧密初期の直線 部の勾配から圧密終了を判定する $\sqrt{t}$ 法は三軸等方圧 密には不適切だと考えられる。

また，Fig.1 からわかるように，体積変化から求めた $t_{100}^{*}$ 付近において, 上部集水の場合は $10 \%$ 程度, 下部 集水では $4 \%$ 程度の過剩間隙水圧が残留している. し かし， $t_{E}$ 付近では上部集水においても過剩間隙水圧が

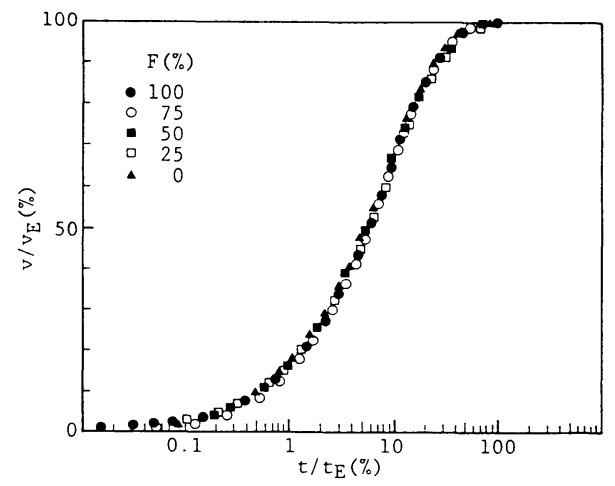

(b) $3 t$ method

Fig. 5 Normalized consolidation curves for five different filter paper coverage. 
十分消散している.

実験終了時の供試体の含水比と圧密時間の関係を Fig. 6 に示す。圧密時間は，各供試体の圧密時間 $\left(t_{c}\right)$ を $t_{E}$ で正替化したものを用いている，カオリン -2 粘土で は，含水比のばらつきがみられるが，その他の粘土にお いては,Fig. 4 の間隙比と時間の関係と同じような傾向 となる. 圧密時間が $t_{E}$ より短い場合は, 含水比の差が $1 \sim 2 \%$ あり, この含水比の差が変形, 強度特性に影響 を及ぼす可能性がある。

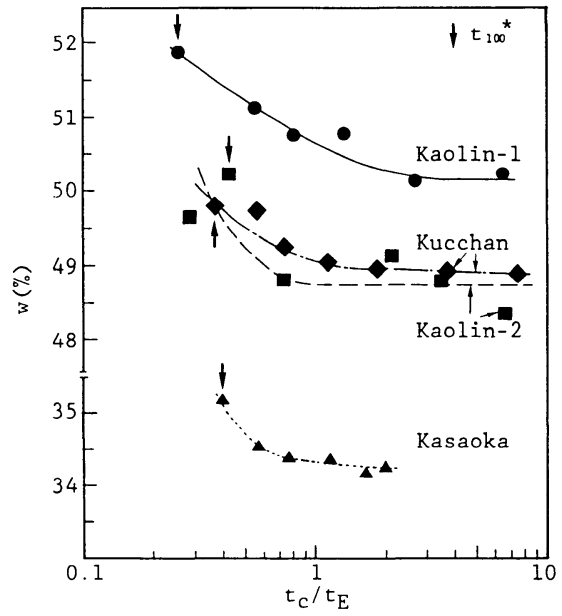

Fig. 6 Water content versus normalized consolidation time.

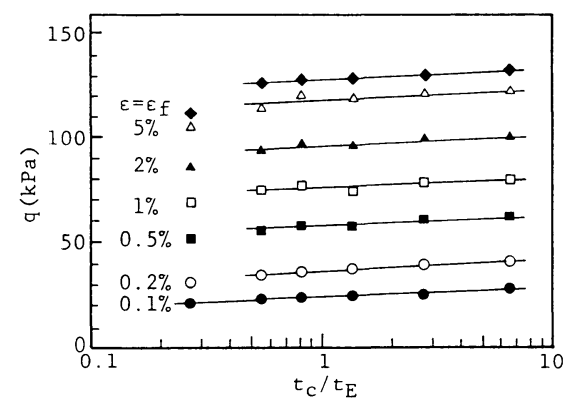

(a) Kaolin-1

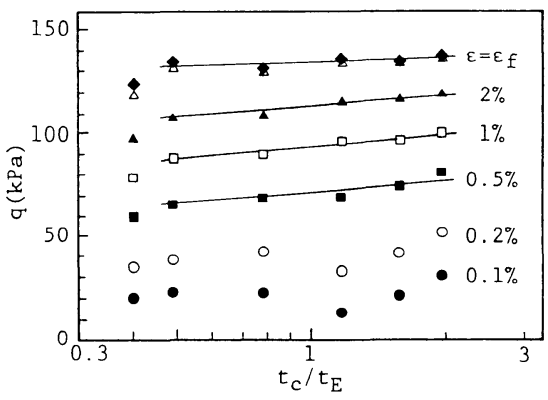

(c) Kasaoka
以上のことを総合すると，三軸等方圧密時の圧密終了 判定法としては， $\sqrt{t}$ 法を準用するよりも $3 t$ 法を用い る方が適当であると考えられる.

\section{（2）变形特性}

a）軸差応力〜軸ひずみ挙動

Fig. 7 (a)〜 (d) は, 各粘土の軸差応力と軸ひずみと の関係から求めた同一軸ひずみにおける軸差応力と $t_{E}$ で正規化した圧密時間の関係を示している. カオリン-1 粘土では, 最も圧密時間の短いもの $\left(t_{c}=t_{100}^{*}\right)$ を除いて, 同一軸ひずみにおける軸差応力は圧密時間に比例して増 加する.この増加率はせん断開始から破壊に至るまで変 わらない. カオリン -2 粘土においても圧密時間が $t_{E}$ よ り短い場合においては, 同一軸ひずみにおける軸差応力 は圧密時間に比例して増加する傾向にある. しかし， $t_{E}$ 以上では圧密時間の影響をほとんど受けない，笠岡粘土 では, $0.5 \%$ 以上の軸ひずみにおいて圧密時間の最も短 いもの $\left(t_{c}=t_{100}^{*}\right)$ を除いて, 軸差応力は圧密時間に比 例して増加する．その増加率は破壊に近づくにつれて小 さくなる，俱知安粘土では，軸ひずみ $0.5 \%$ 以上にお いて同一軸ひずみにおける軸差応力は圧密時間に比例し て増加する。しかし $1 \%$ 以上において, 圧密時間 $t_{E}$ を 交点とする 2 直線となり，その増加率は $t_{E}$ より短い方 が大きい. $t_{E}$ 以上においては笠岡粘土と同じく破壊に 近づくにつれて小さくなる．笠岡，俱知安粘土は，圧密 時間の増加とともに小ひずみ域で軸差応力が急激に立ち

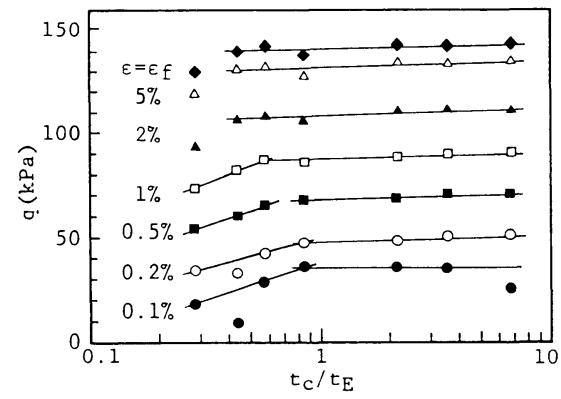

(b) Kaolin-2

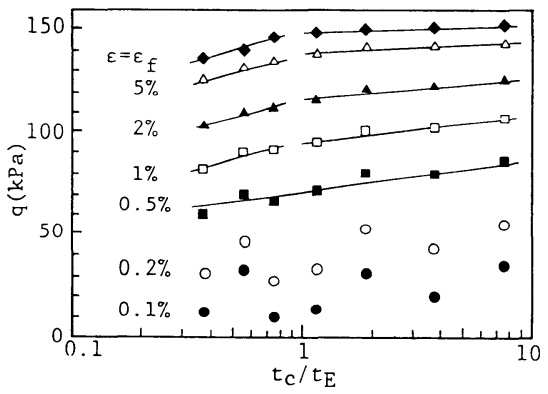

(d) Kucchan

Fig. 7 Deviator stress versus normalized consolidation time. 
上がり，その最大值はわずかに増加の傾向を示すとした 報告 $\left.{ }^{1)}, 4\right), 51,81$ と同じ挙動となった.

以上の結果から, 圧密時間の増加に伴い同一軸ひずみ における軸差応力は増加する.この傾向は粘土の種類に より差はあるが圧密時間の短いものの方がその影響を大 きく受けるので, 圧密時間は $t_{E}$ より長くした方がよい と考えられる.

\section{b）間隙水圧〜軸ひずみ挙動}

各粘土のせん断時における発生間隙水圧と軸ひずみと の関係から軸差応力と同様に軸ひずみをパラメーターと した発生間隙水圧と圧密時間の関係を Fig. 8(a) (d) に示す. 圧密時間の短いものでは, せん断開始時にもま だ間隙水圧が残留しているが，せん断開始時からの間陌 水圧の発生量で整理している.

これらの図からわかるように，カオリン $-1,2$ 粘土に おいては, 同一軸ひずみにおける間隙水圧は, ひずみの 小さい領域では圧密時間の影響を受けないがひずみが大 きくなるに従って圧密時間に比例して減少している。ま た，笠岡粘土においては，軸ひずみ $2 \sim 3 \%$ において， やや圧密時間に比例して増加する傾向があるが，圧密圧 力の影響を受けないといってよい. 俱知安粘土において はせん断時の間陌水圧は圧密時間の影響をほとんど受け ない. 各粘士とも軸差応力のように圧密時間の短いもの が異なった挙動を示すような傾向はない.

本実験において圧密時間の最も短いものでの残留間隙

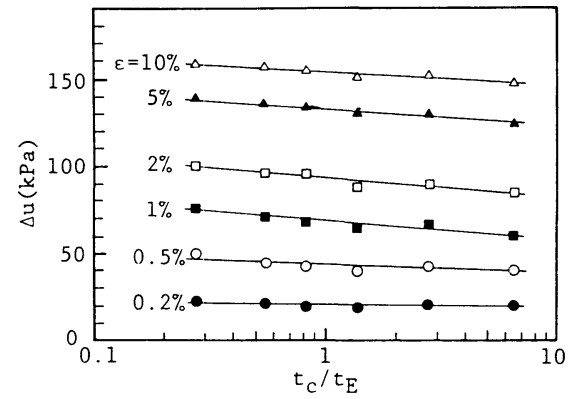

(a) Kaolin-1

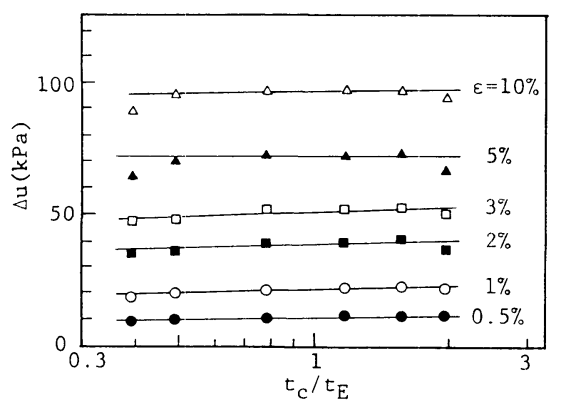

(c) Kasaoka
水圧は, カオリン $-1,2$ 粘土では, それぞれ圧密圧力の $1.7,1.8 \%$ 程度，笠岡粘土は $10 \%$, 俱知安粘土は $5 \%$ であった. したがって, 笠岡, 俱知安粘土の圧密時間の 短いものでは所定の有効圧密圧力に達していなかったと 考えられ, せん断開始時の有効応力で縦軸を正規化すれ ば, カオリン粘土のような挙動を示すことも考えられる. しかし, 前述のように圧密時間の短い場合は間隙水圧の 測定が不確実であり, 正確な有効圧密圧力が得られない ため行っていない.

Bjerrum ら ${ }^{1)}$ は, せん断時の間隙水圧は圧密時間の影 響を受けないことを報告している．また，山口ら せん断時の間隙水圧挙動に及ぼす圧密時間の影響につい て, せん断初期には, 圧密時間の長いものほど間隙水圧 の発生量が少ないが, 破壊時にはほとんど等しくなると している，また，ひずみ速度が遅い場合には，せん断中 の間隙水圧は圧密時間の影響を受けないとしている．非 排水せん断において間隙水圧の均一化に必要なひずみ速 度を圧密時の圧密係数の関数として決める方法 ${ }^{19}$ が提案 $^{-}$ されている. Table 4 から判断して笠岡, 俱知安両粘土 におけるひずみ速度は, カオリン粘土と比較しても遅い とはいえない, さらに, 亀井ら ${ }^{10)}$ は, 圧密時間の増加と ともに間隙水圧が減少することを報告しているが, 彼ら は発生間隙水圧に圧密時の残留間隙水圧も含めている.

以上のことからわかるように，非排水せん断時の間隙 水圧挙動に及ぼす珐密時間の影響については, 過去の研

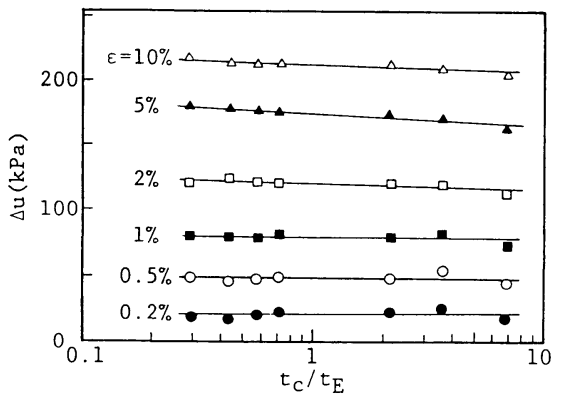

(b) Kaolin-2

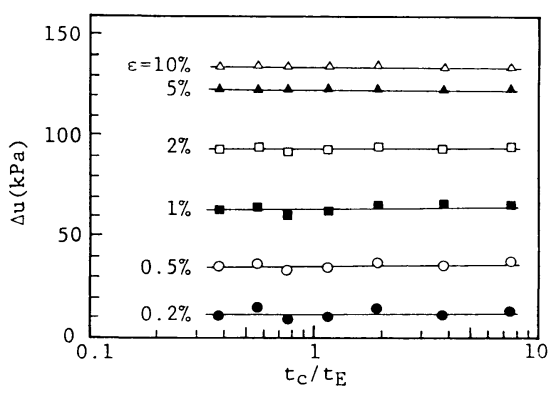

(d) Kucchan

Fig. 8 Induced pore water pressure versus normalized consolidation time. 
究においても一致した見解は得られていない，また，本 実験の結果からも十分な結論は得られなかった。この点 についてはさらに検討を要する.

c) 有効応力経路

Fig. 9(a) （d) に各粘土の有効応力経路を示す.こ の図からわかるように亀井ら ${ }^{10)}$ の実験結果ほどには圧密 時間の長:短によってせん断開始時の応力状態に差は生じ ていないが, 圧密時間の異なる各試料の有効応力経路は ほぼ相似な形状を示している．三笠ら゙放告している ように，ひずみ速度を変えて行ったカオリン-1 粘土お よび笠岡粘土の実験201,21) から得られた有効応力経路も同 様な傾向を示している。

\section{（3）強度特性}

圧密時間と各強度定数との関係を Fig. 10(a) (d) に 示す. 压密時間は, $t_{E}$ で正規化したものを示している.

a) 非排水強度

Fig. 10(a) からわかるように, 各粘土とも, 圧密時間 の短い一部のものを除き, 圧密時間の対数に比例して非 排水強度が大きくなる，この傾向は，二次圧密係数が小

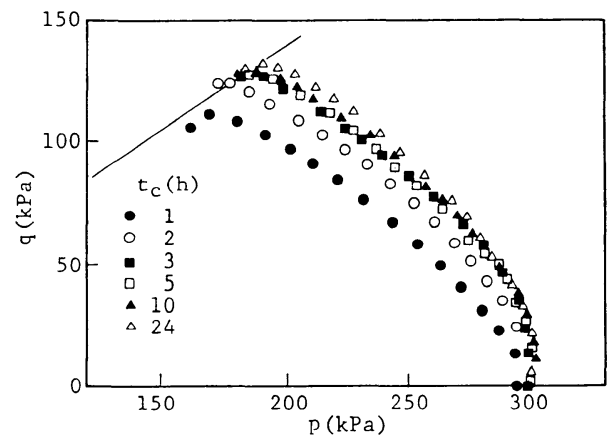

(a) Kaolin-1

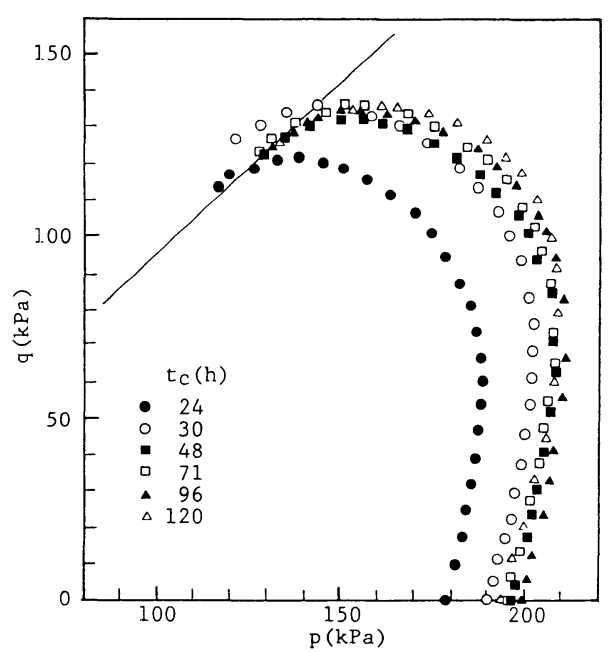

(c) Kasaoka
さいカオリン -2 粘土が小さいが，二次圧密係数に比例 するともいえない.カオリン-2粘土においては $t_{100}^{*} よ$ り小さい場合, カオリン -1 粘土, 俱知安粘土において は $t_{100}^{*}$ の 2 倍より小さい場合において急激に強度が下 がる傾向がある. 亀井ら ${ }^{10}$ も同様な実験結果を報告して いる.

しかし，本実験では間隙水圧測定経路に近いところで 集水しており, 圧密中の間隙水圧の值が供試体内の平均 値よりも低めに測定されている可能性があり，圧密時間 の短い場合には圧密終了時の有効応力を過大に評価して いることも考えられる. したがって, 供試体の平均有効 応力が正しく測定でき，それで正規化すればこの直線上 にのる可能性もある。

三笠ら 速めることはせん断時の挙動に類似の影響を与えること を報告している．本実験および他の研究者による実験か ら得られた，圧密時間およびひずみ速度の増加による強 度の増加率を Table 5 に示す．この表からわかるように この 2 つ挙動に類似性があることがわかる.

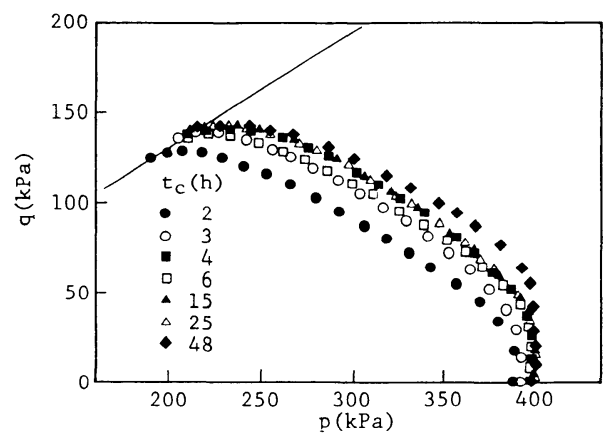

(b) Kaolin-2

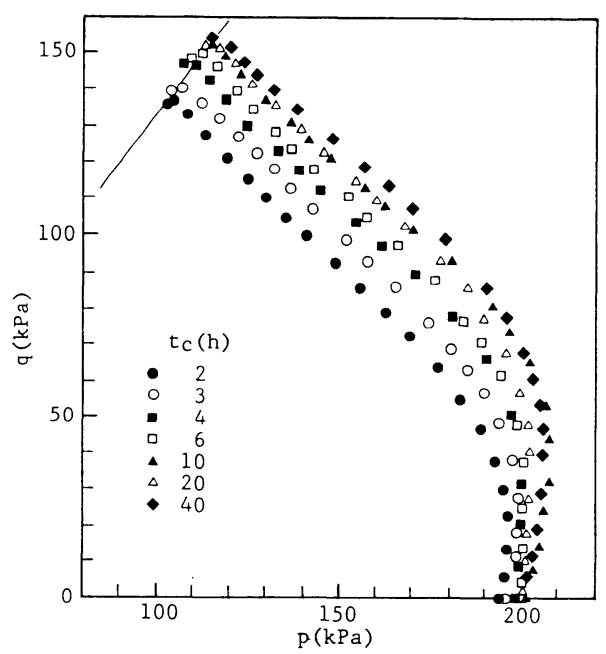

(d) Kucchan

Fig. 9 Effective stress paths. 
b）破壊時における軸ひずみ

Bjerrum ら ${ }^{1)}$ は, 乱さない粘土を用いた圧密非排水試 験結果から圧密時間の増加に伴い軸差応力はより小さい ひずみでその最大值を与えることを報告している．しか し，本実験の圧密時間の範囲では明瞭な傾向がみられな かった。また，北郷ら や)や山口ら も練り返した粘土を 用いた実験結果から圧密時間は破壊時の軸ひずみに影響 を及ぼさないとしている。三田地ら ${ }^{5)}$ は，北郷ら ${ }^{4)}$ の実 験と同じ試料を用い $K_{0}$ 圧密した場合には，破壊時の軸 ひずみは，圧密時間の短い方が大きいことを報告してい る.

本実験は, 圧密非排水試験における圧密終了時間の判 定を対象としているため圧密時間が比較的短期間であっ たので，疑似過圧密的挙動が現われなかったことによる

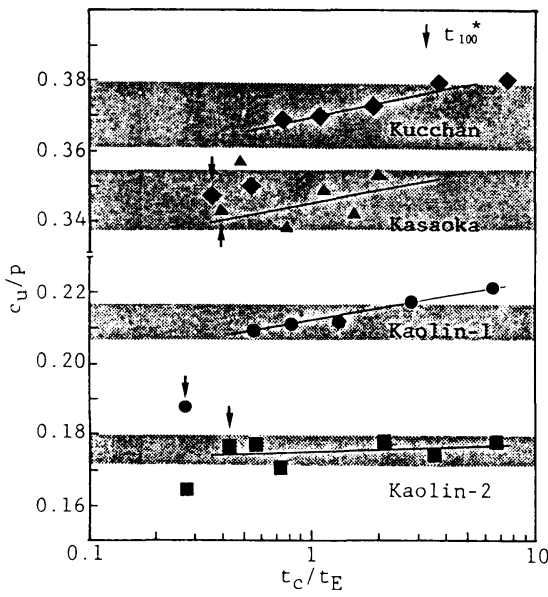

(a) Rate of strength increase

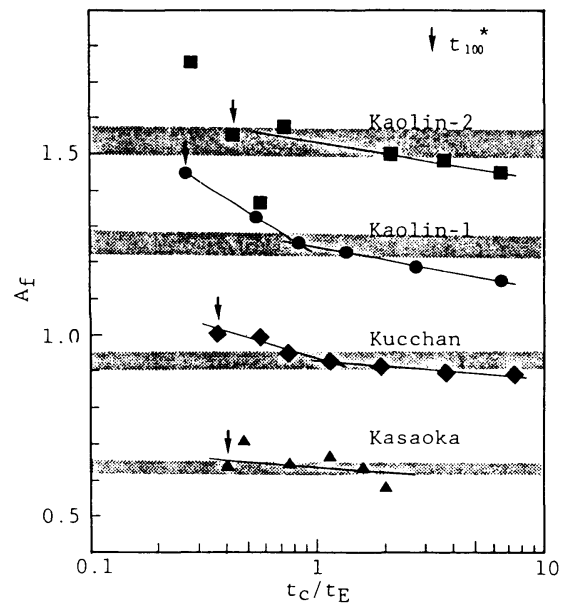

(c) Pore pressure coefficient at failure
ものと思われる.

c）破壊時の間隙水圧係数

破壊時の間隙水圧係数に及ぼす圧密時間の影響につい て, Bjerrum ら ${ }^{1)}$ は, 圧密時間の増加に伴い減少するこ とを報告している．また，亀井ら ${ }^{10)}$ は $t_{E}$ 以下では圧密 時間の増加に伴い増加するが，それ以上では一定になる 実験結果を示している.

破壊時の間隙水圧係数は, Fig. 10(c) からわかるよう に圧密時間の増加に伴い減少する傾向となる.しかし, 笠岡粘土以外は， $t_{E}$ を交点とする 2 直線で表わすこと ができ， $t_{E}$ より短い範囲で圧密時間の影響が大きい。

d）有効応力によるせん断抵抗角

有効主応力比 $\sigma_{1}^{\prime} / \sigma_{3}^{\prime}$ の最大值から求めた有効応力によ るせん断抵抗角を Fig. 10(d) に示す. 有効応力による

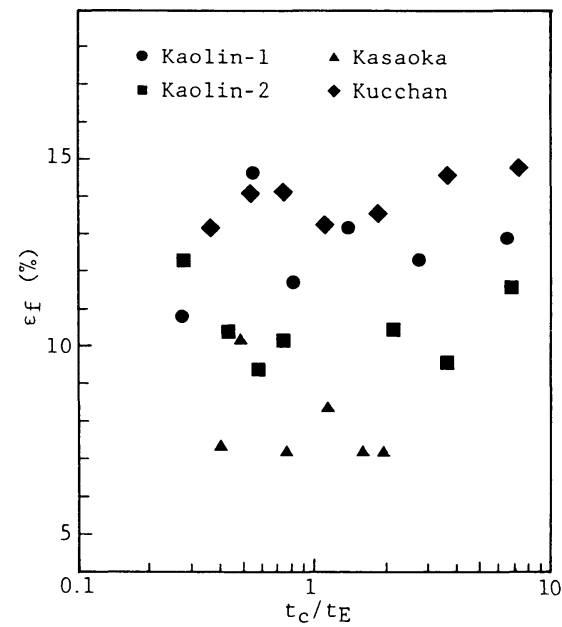

(b) Axial strain at failure

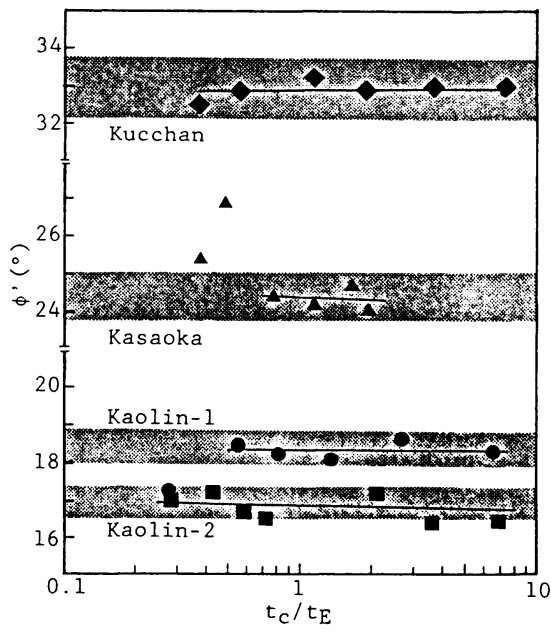

(d) Angle of shear resistance (in terms of effective stress)

Fig. 10 Strength parameters. 
Table 5 Undrained strength increase by increment of strain rate and consolidation duration.

\begin{tabular}{l|c|c|c}
\hline \multirow{2}{*}{ Sample } & Increment for l log cycle(\%) & \multirow{2}{*}{ Remark } \\
\cline { 2 - 3 } & aging & strain rate & \\
\hline Kaolin-1 & 5.3 & 9.0 & \\
\hline Kaolin-2 & 1.1 & 3.5 & \\
\hline Kasaoka & 3.6 & 2.2 & \\
\hline Kucchan & 3.5 & - & \\
\hline Haney & 7.0 & $7.0 *$ & Ref. 7) \\
\hline Ohnegai & 3.7 & 2.8 & Ref. 8) \\
\hline
\end{tabular}

せん断抵抗角は，圧密時間に関係なくほぼ一定となる。 過去の研究者も ${ }^{11,31,4), 81,99}$ 同様な結果を報告している. ま た，北鄉ら ${ }^{4)}$ は， 3 種類の練り返した粘土の圧密非排水 試験結果から，12 時間で圧密した場合の有効応力によ るせん断抵抗角は，2 3 時間で一次圧密が終了してい るにもかかわらず，すべての試料において 24 時間以上 圧密した場合より大きな值となることを報告している.

e) 各強度定数に及ぼす圧密時間の影響

Fig. 10(a), (c), (d) に $t_{E}$ における各強度定数の士 $2.5 \%$ の範囲を示している。 これらの図からわかるよう に非排水強度に及ぼす圧密時間の影響を $5 \%$ 以内に抑 えるためには, 圧密時間を $t_{E}$ の 0.5 から 3 倍, あるい は $\sqrt{t}$ 法を準用するのであれば, $t_{100}^{*}$ の 2 倍から 8 倍之 すればよい，また，破壊時の間隙水圧係数においては， $t_{E}$ の 0.8 から 2 倍, $t_{100}^{*}$ の 3 倍から 5 倍とすればよい.

\section{4. 結 論}

4 種類の粘性土に対し圧密時間を変えて行った圧密非 排水試験の結果から以下のことがわかった.

（1）三軸等方圧密においても $\sqrt{t}$ 法の適用が可能 であるが，圧密終了の判定法として， $3 t$ 法が適当であ る.

（2）軸差応力〜ひずみ関係は，粘土の種類によりそ の傾向は多少異なるがせん断開始から破壊に至るまで圧 密時間の影響を受ける.

（３）せん断時に発生する間隙水圧は，圧密時間の増 加に伴い減少する可能性がある.

（4）非排水せん断強度は圧密時間の対数に比例して 増加する. その増加率は $t_{E}$ より短い方が大きい.

（5）破壊時の間隙圧係数は圧密時間の増加とともに 減少する，その減少率は $t_{E}$ より短い方が大きい.

（6）有効応力によるせん断抵抗角は圧密時間の影響 を受け五一定である.

（7） $t_{E}$ の 70 250\%の範囲では強度定数の差は, 5 $\%$ 以内之なる.

以上の結果から，せん断抵抗角を除いては，強度に関 するパラメーターは圧密時間の影響を受けるが, 圧密過程
における挙動から判断して三軸圧密非排水試験における 圧密終了時間の判定法としては, $3 t$ 法が適当だと考え られる。

\section{5. おわりに}

今回用いた試料はすべて練り返し予圧密して作成し, 三軸セル内で圧密した正規圧密粘土であり，理想的な状 態と考えてよい。 さらに，種々の応力および時間履歴を 受けている乱さない粘土についても検討する必要があろ う.

\section{参 考 文 献}

1) Bjerrum, L. and Lo, K. Y. : Effect of Aging on the shear strength properties of a normally consolidated clay, Geotechnique, Vol.13, No.2, pp. 147 157, 1963.

2）三笠正人・木下哲生：粘性土の圧密時間とせん断強さに ついて, 第 25 回土木学会年次講演会講演概要集, pp. 159 162, 1970.

3）三笠正人 · 木下哲生・高田直俊 : 粘性土の圧密時間とせ ん断強さについて (第 2 報), 第 6 回土質工学研究発表会 講演集, pp. 137 140, 1971.

4）北郷 繁・三田地利之：粘性土の強度特性に及ぼす圧密 時間の影響, 第 7 回土質工学研究発表会講演集, pp. 197 $\sim 200,1972$.

5）三田地利之・北郷 繁・唐牛義夫：粘性土の強度特性に 及ぼす圧密時間の影響（第 3 報），第 8 回土質工学研究発 表会講演集, pp. 299～302, 1973.

6) Shen, C. K., Arulanandan, K. and Smith, W.S. : Secondary consolidation and strength of a clay, Proc. ASCE, Vol.99, SM1, pp.95 110, 1973.

7) Vaid, Y.P. and Campanella, R. G. : Time-dependent behavior of undisturbed clay, Proc. ASCE, Vol.103, No. GT7, pp. 693 709, 1977.

8）山口晴幸 ·三田地利之 · 北郷 繁 : 練返し 飽和粘性土の 非排水応力ーひずみ一強度挙動に及ぼす二次圧密の影響, 土質工学会論文報告集, Vol. 21, No. 3, pp. 123 131, 1981.

9) Yasuhara, K. and Ue, S. : Increase in undrained shear strength due to secondary compression, Soils and Foundations, Vol.23, No. 3, pp. 50 64, 1983.

10) Kamei, T., Ogawa, S. and Tanaka, N. : The variation in undrained shear characteristics during consolidation process, Soils and Foundations, Vol.27, No. 3, pp. 91 98, 1987.

11）土質工学会編：三軸圧縮試験, 土質試験法, 第 2 回改訂版, 1979.

12）三軸試験基準化委員会：土の三軸圧縮試験法一土質工学 会基準案一について, 第 20 回土質工学シンポジウム—— 軸および三軸圧縮試験法とその応用一, pp. 15〜44, 1975.

13）奥田 薫 - 小田美明 -三田地利之：粘性土の圧密非排水 試験に及ぼす圧密圧力の載荷段階数の影響, 第 43 回土木 学会年次講演会講演概要集, pp. 518 519, 1988.

14) Berre, T. : Suggested international code of soil engineering practice for consolidated triaxial tests, Norwe- 
gian Geotechnical Institute, Internal report 56103-30, 1985.

15) Mitachi, T., Kohata, Y. and Kudoh, Y. : The influence of filter strip shape on consolidated undrained triaxial extension test results, Advanced triaxial testing of soil and rock, ASTM STP 977, pp. 667 678, 1988.

16）三笠正人：軟弱粘土の圧密〈新圧密理論とその応用 $>$, 鹿島出版会, 1963.

17) Shimizu, M. : Factors affecting the measurement of volume change of cohesive soils in drained triaxial tests, Soils and Foundations, Vol.21, No.2, pp. 121 128, 1981.

18）三田地利之・成田 孝：三軸試験の体積変化測定におよ
ぼすろ紙の圧縮性およびゴム膜の透水性の影響, 第 20 回 土質工学研究発表会講演集, pp. 186 189, 1985.

19) Bishop, A. W. and Henkel, D. J. : The measurement of soil properties in the triaxial test, Edward Arnold Ltd. , London, 1962.

20）三田地利之：異方圧密粘土の構成式と土質パラメータ決 定法に関する研究, 昭和 63 年度文部省科学研究費 (一般 研究C）研究成果報告, 1989 .

21）小田美明・三田地利之：正規圧密粘性土の応力〜ひずみ 一時間挙動, 土質工学会北海道支部技術報告集, Vol. 27, pp. $67 \sim 74,1987$.

(1989.5.1 • 受付) 